\title{
ANALISA TINGKAT PEMAHAMAN DAN MISKONSEPSI PADA MATERI LISTRIK STATIS MAHASISWA TADRIS FISIKA MENGGUNAKAN METODE 3-TIER MULTIPLE CHOICES DIAGNOSTIC
}

\author{
Lalu A. Didik ${ }^{1}$, Fitratul Aulia ${ }^{2}$ \\ ${ }^{1,2}$ Program Studi Tadris Fisika, Fakultas Tarbiyah dan Keguruan UIN Mataram
}

\begin{abstract}
An analysis of the level of understanding and misconception of Tadris Physics students at Mataram State Islamic University has been carried out. The sub material tested was adjusted to the Student Semester Learning Plan in the Electric Magnet Course which included the Coulomb Style, Electric Field and Electric Potential. The method used is 3-Tier Multiple Choices. In this method there are three stages of student answers namely concept answers, reasons and levels of confidence. Based on the results of diagnostic tests on students obtained a level of full understanding of students by $42.92 \%$ and misconception levels of $23.61 \%$. Students experience the biggest misconception in the electric field sub material that is equal to $37.50 \%$ and the lowest in the material potential electricity that is equal to $10 \%$. Although the percentage of misconceptions is relatively small, there are still students who experience misconceptions in each submission.

Keywords: Misconceptions, Static Electricity, 3-Tier Multiple Choices Diagnostic
\end{abstract}

\begin{abstract}
Abstrak
Telah dilakukan analisa tingkat pemahaman dan miskonsepsi mahasiswa Tadris Fisika Universitas Islam Negeri Mataram. Sub materi yang diuji disesuaikan dengan Rencana Pembelajaran Semester Mahasiswa pada Mata Kuliah Listrik Magnet yang mencakup Gaya Coulomb, Medan Listrik dan Potensial Listrik. Metode yang digunakan adalah 3-Tier Multiple Choices. Dalam metode ini ada tiga tahap jawaban mahasiswa yaitu jawaban konsep, alasan dan tingkat keyakinan. Berdasarkan hasil tes diagnostik terhadap mahasiswa diperoleh tingkat pemahaman penuh mahasiswa sebesar 42,92\% dan tingkat miskonsepsi sebesar 23,61\%. Mahasiswa mengalami miskonsepsi terbesar pada sub materi Medan listrik yaitu sebesar 37,50\% dan terendah pada materi potensial listrik yaitu sebesar 10\%. Walaupun persentase miskonsepsi tergolong kecil namun masih ada mahasiswa yang mengalami miskonsepsi pada setiap submateri.
\end{abstract}

Kata kunci: Miskonsepsi, Listrik Statis, 3-Tier Multiple Choices Diagnostic

Program Studi Tadris Fisika UIN Mataram

Email: laludidik@uinmataram.ac.id
(C2019 Universitas Islam Negeri Walisongo 99 ISSN: 2088-7868, e-ISSN 2502-5708 


\section{PENDAHULUAN}

Pembelajaran fisika merupakan pembelajaran yang dilakukan mahasiswa dengan cara mengkaitkan kejadian-kejadian alam di sekitarnya. Tujuan pembelajaran fisika adalah menguasai pengetahuan (konsep) (Suparno. 2007). Fisika dikelompokkan sebagai pengetahuan fisis yang terjadi karena abstraksi terhadap alam dunia ini. Hal ini menunjukkan bahwa pembelajaran fisika berhubungan dengan penguasaan konsep yang berhubungan dengan alam.

Setiap mahasiswa mempunyai daya yang berbeda dalam menghubungkan konsep fisika dengan kejadian alam. Mahasiswa juga dapat mengalami kesalahan dalam menghubungkan konsep fisika yang mereka pelajari sehingga dapat menyebabkan perbedaan antara konsep yang mereka bentuk sendiri demngan konsep yang dibentuk oleh para ahli. Hal ini disebabkan karena mahsiswa mempunyai cara yang berbeda dalam membangun abstraksi konsep fisika. Tafsiran seseorang terhadap suatu konsep disebut sebagai konsepsi (Berg.1991). Pemahaman konsep merupakan salah satu faktor penting dalam pembelajaran fisika (Maulida dkk. 2017).

Siswa seringkali sudah mempunyai konsep awal tentang fisika yang biasanya diperoleh dari pengalaman, orang tua, lingkungan siswa, dan dipendidikan sebelumnya ketika mengikuti proses pembelajaran secara formal. konsep awal yang dimiliki siswa kadang-kadang tidak sesuai dengan konsep para ilmuwan. Konsep awal yang didapat dari pengalaman dan pendidikan sebelumnya yang tidak sesuai dengan konsep para ilmuwan biasanya disebut miskonsepsi atau salah konsep akan berathan lama, hal tersebut sesuai dengan pendapat Suparno ( 2005; 2 ) Miskonsepsi siswa biasanya bertahan lama dan sulit diperbaiki, karena konsep awal yang dimiliki siswa meskipun keliru tetapi dapat menjelaskan persoalan hidup yang mereka hadapi. Kucuk et al., (2005) menyatakan miskonsepsi adalah konsep yang tidak sesuai dengan konsep yang berkembang.

Miskonsepsi terjadi pada jenjang pendidikan terendah sampai tertinggi dari sekolah dasar sampai dengan perguruan tinggi. Miskonsepsi banyak terjadi terutama bagi mahasiswa dengan kemampuan menganalisa yang kurang. Biasanya miskonsepsi terjadi pada mahasiswa pada saat menghubungkan suatu konsep yang terdiri dari beberapa konsep dasar sehingga membutuhkan pemahaman konsep yang 
lebih mendalam. Sesuai hasil penelitian-penelitian sebelumnya sebagai berikut Khasanah dan Setiawan (2015) menyatakan miskonsepsi mahasiswa fisika materi listrik statis menggunakan tes konsep listrik statis didapat informasi mahasiswa mengalami miskonsepsi $8 \%$, tidak paham 48\%, dan paham $44 \%$. Sejalan dengan Sukadi dan Ira (2013) miskonsepsi mahasiswa fisika tentang listrik statis adalah sebanyak 45,8\% mahasiswa miskonsepsi dalam mengartikan benda yang disebut positif, sebanyak 10,8\% mahasiswa miskonsepsi dalam mengartikan benda yang disebut negatif, sebanyak $82,1 \%$ mahasiswa miskonsepsi dalam mengartikan benda yang disebut netral, sebanyak 72,5\% mahasiswa mengalami miskonsepsi dalam memahami benda yang dikatakan bermuatan listrik, sebanyak 42,8\% mahasiswa mengalami miskonsepsi dalam menjelaskan perpindahan muatan dengan menggosok penggaris pada kain wol, sebanyak 38,3\% siswa miskonsepsi dalam menjelaskan perpindahan muatan dengan menggosok kaca pada kain sutra, sebanyak $71,7 \%$ mahasiswa miskonsepsi yang menganggap sifat muatan yang sejenis akan tarik menarik, sebanyak 69,2\% mahasiswa miskonsepsi yang menganggap sifat muatan yang tidak sejenis akan tolak menolak, dan sebanyak 68,3\% mahasiswa mengalami miskonsepsi dalam memahami konsep hukum coulomb yaitu hubungan antara gaya coulomb, muatan dan jarak antara dua muatan. Sehingga dapat disimpulkan bahwa miskonsepsi yang dialami mahasiswa pada materi listrik statis cukup besar.

Dalam riset miskonsepsi di Indonesia, bedasarkan jenjang pendidikan dari SD, SMP, SMA dan perguruan tinggi memiliki miskonsepsi yang sama dan berbeda-beda. Berdasarkan kelamin / jender, juga ada perbedaan tingkat persentase (\%) miskonsepsi. Siswa yang berminat dalam pelajaran fisika cenderung memiliki miskonsepsi yang lebih rendah daripada siswa yang kurang berminat dalam pelajaran fisika (Suparno, 2005: 133).

Ada beberapa cara untuk membantu mahasiswa mengurangi atau mengatasi miskonsepsi. Kesalahan mahasiswa dapat beraneka ragam maka diperlukan penanganan yang berbeda pada setiap mahasiswa. Maka penting bagi pengajar untuk mengetahui dan mengerti miskonsepsi yang telah dialami mahasiswa. Beberapa cara mendeteksi miskonsepsi siswa yang biasa digunakan peneliti antara lain: tes esai, tes pilihan ganda, tes multiple choices dengan alasan terbuka sesuai pendapat Gurel, et. al. (2015) bahwa miskonsepsi pada siswa dapat diukur dengan berbagai cara yaitu 
pembuatan peta konsep, tes diagnostik, wawancara, diskusi dalam kelas, dan praktikum melalui tanya jawab. Pada penelitian ini peneliti menggunakan tes diagnostik digunakan sebagai upaya untuk mencari kesalahan pemahaman siswa (Dwi Roro Ambarwati. 2011; Desvi. 2009). Tes diagnostik dengan pendekatan miskonsepsi digunakan untuk mengidentifikasi kemampuan mahasiswa dalam menangkap suatu konsep yang mereka bangun berdasarkan pengalaman - pengalaman belajar yang telah mereka lakukan. Instrumen diagnostik 3TMC test dengan aspek literasi sains digunakan untuk mengungkap dan menemukan bentuk miskonsepsi literasi sains peserta didik (Sri Wahyuningsih, Ani Rusilowati, Nathan Hindarto. 2018). Ukuran tingkat keyakinan/kepastian responden dalam menjawab setiap pertanyaan (soal) yang diberikan, yang dikembangkan untuk dapat membedakan antara siswa yang mengalami miskonsepsi dan tidak tahu konsep disebut certainty of response index (CRI) (Tayubi, 2005: 9). Berdasarkan uraian di atas, penelitian bertujuan untuk menggali miskonsepsi siswa pada materi listrik statis pada mahasiswa Program Studi Tadris Fisika Fakultas Tarbiyah dan Keguruan Universitas (FTK) Islam Negeri (UIN) Mataram.

\section{METODE PENELITIAN}

Penelitian ini adalah penelitian kualitatif survei. Populasi dalam penelitian ini dilaksanakan di Program Studi Tadris Fisika Fakultas Tarbiyah dan Keguruan Universitas (FTK) Islam Negeri (UIN) Mataram. Sampel diambil dari mahasiswa Semester V Prodi Tadris Fisika Semester Ganjil Tahun Akademik 2017/2018 yang berjumlah 20 orang.

Tabel 1. Kriteria Penilaian Miskonsepsi Mahasiswa Tadris Fisika

\begin{tabular}{|c|c|c|}
\hline NO & TIPE RESPON & KATEGORI \\
\hline 1 & Jawaban Benar + Alasan Benar + yakin & Pengetahuan Penuh \\
\hline \multirow[t]{5}{*}{2} & - Jawaban Benar + Alasan Benar + tidak yakin & Paham Sebagian \\
\hline & - Jawaban Salah + Alasan Benar + tidak yakin & \\
\hline & - Jawaban Benar + Alasan Salah + tidak yakin & \\
\hline & - Jawaban Salah + Alasan Benar + yakin & \\
\hline & - Jawaban Benar + Alasan Salah + yakin & \\
\hline 3 & Jawaban Salah + alasan salah namun masih berhubungan & Miskonsepsi \\
\hline
\end{tabular}




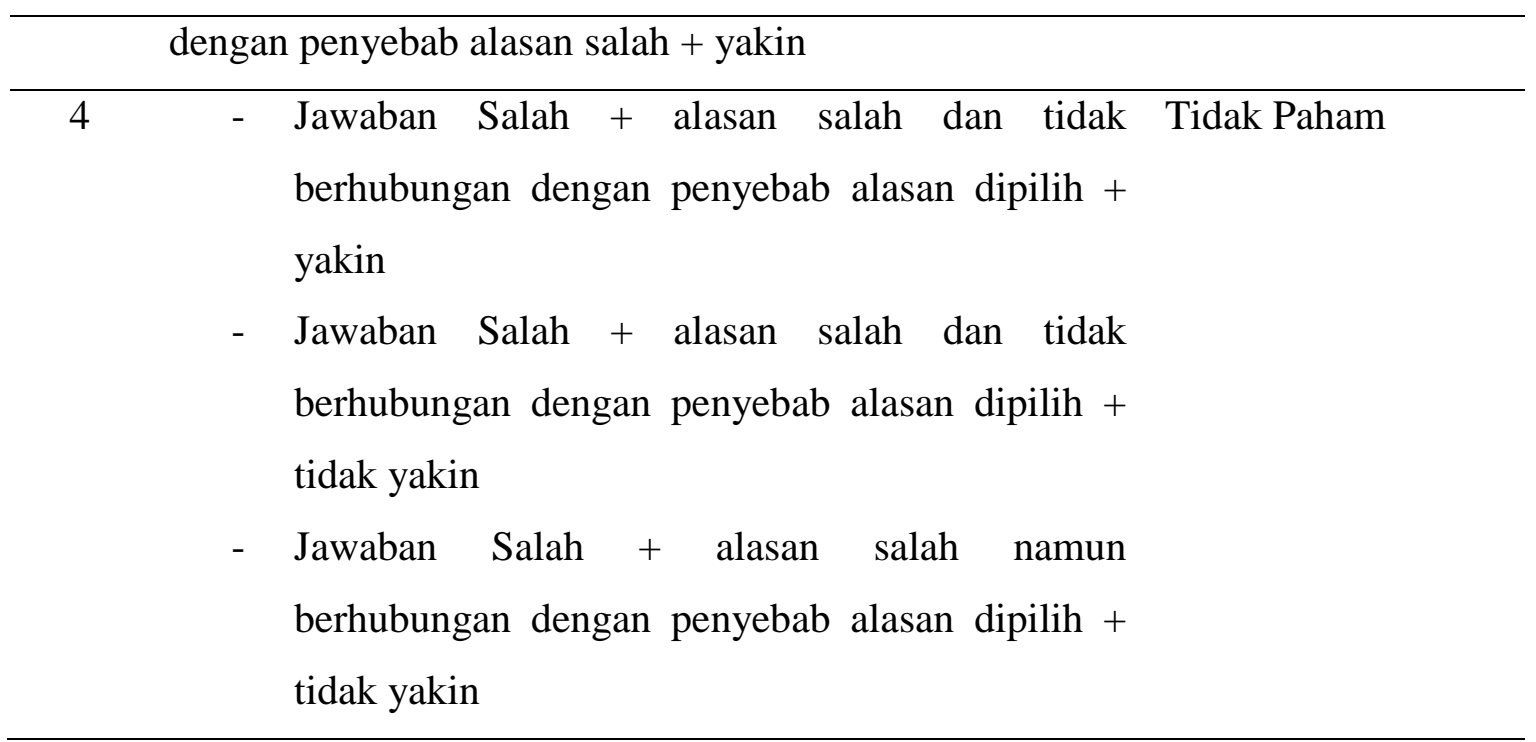

Penelitian ini merupakan penelitian survei. Angket penelitian dilakukan dengan menyebar 10 soal miskonsepsi kepada mahasiswa dengan indikator Gaya Coulomb, Medan Listrik dan Potensial Listrik.

Tes yang digunakan dalam penelitian ini adalah tes diagnostik dengan metode 3tier multiple choices. Soal yang digunakan adalah soal konsep dengan tipe jawaban opsional Benar atau Salah namun dengan penjelasan jawaban dibuat opsional. Kriteria penilaian untuk mengiedentifikasi adanya miskonsepsi menggunakan format seperti yang ditunjukkan pada Tabel 1 (Pesman. 2005).

Tes diagnostik dibuat untuk mengetahui tipe kesalahan mahasiswa, dimana dalam kasus penelitian ini adalah mengenai miskonsepsi. Tes ini menggunakan acuan kriteria pada tabel 1, yang digunakan untuk membandingkan hasil analisis yang didapat tentang kondisi siswa dengan kesimpulan menempatkan posisi siswa dalam kriteria.

Penyusunan instrumen penelitian dilakukan dengan telaah pustaka pada subbab gaya coulomb, medan listrik dan potensial listrik. Dalam memformulasikan daftar pertanyaan, perlu diperhatikan susunan kalimat yang logis sehingga responden dapat memahami makna yang terkandung dalam pertanyaan tersebut. Secara umum prosedur penelitian yang dilakukan digambarkan dalam Gambar 1. 


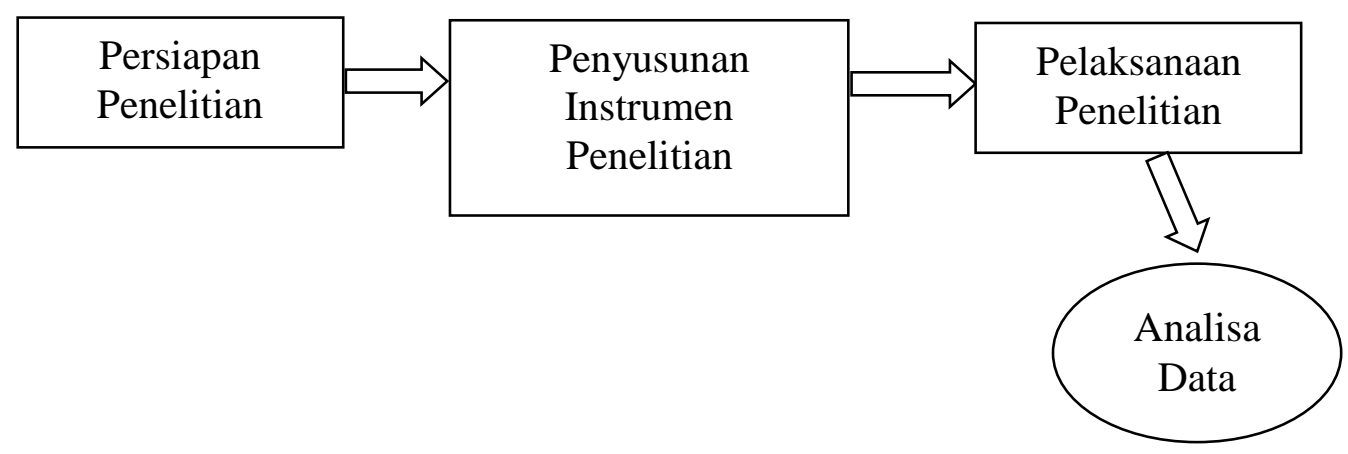

Gambar 1. Prosedur Penelitian

Mahasiswa dikatakan mengalami miskonsepsi apabila memberikan jawaban dan alasan dengan salah namun memiliki tingkat keyakinan yang tinggi dalam memberikan jawaban. Prosentase miskonsepsi dapat dihitung dengan persamaan berikut

$$
M S=\frac{n}{N} \times 100 \%
$$

Dimana,

MS : Prosentase miskonsepsi

n : jumlah miskonsepsi

$\mathrm{N} \quad$ : jumlah soal $\mathrm{x}$ jumlah mahasiswa

Mahasiswa dikatakan mengalami miskonsepsiapabila memberikan jawaban dan alasan dengan benar serta memiliki tingkat keyakinan yang tinggi dalam memberikan jawaban. Prosentase pemahaman mahasiswa dapat dihitung dengan persamaan berikut

$$
P P=\frac{n}{N} \times 100 \%
$$

Dimana,

PP : Prosentase pemahaman penuh mahasiswa

n : jumlah pemahaman penuh

$\mathrm{N} \quad$ : jumlah soal $\mathrm{x}$ jumlah mahasiswa

\section{HASIL DAN PEMBAHASAN}

Pada penelitian ini, peneliti hanya sebagai pengamat sedangkan untuk proses pembelajaran dilaksanakan langsung oleh dosen pengampu mata kuliah listrik magnet. Tes tertulis diberikan setelah semua materi diberikan sehingga diharapkan dapat 
mengungkapkan miskonsepsi yang mungkin di alami oleh mahasiswa pada materi Gaya Coulomb, Medan Listrik dan Potensial Listrik. Adapun konsep-konsep yang diujikan ditunjukkan pada Tabel 2.

Tabel 2 Sebaran Soal Miskonsepsi Berdasarkan Rencana Pembelajaran Semester (RPS)

Program Studi Tadris Fisika UIN Mataram

\begin{tabular}{clc}
\hline NO & \multicolumn{3}{c}{ KOMPETENSI DASAR } & NOMOR SOAL \\
\hline 1 & Memahami konsep Hukum Coulomb & $1,2,10$ \\
& dalam Sistem Muatan Titik dan & \\
& Terdistribusi Kontinu & $3,6,8,9$ \\
\hline 2 & Menganalisis tentang medan listrik pada & \\
& beberapa distribusi muatan serta \\
& menentukan konservasi medan listrik & $4,5,7$ \\
\hline 3 & Menganalisa potensial skalar pada & \\
& beberapa distribusi muatan
\end{tabular}

Berdasarkan Tabel 2 tampak bahwa soal yang digunakan sesuai dengan indikator yang diinginkan dalam penelitian ini. Jawaban mahasiswa kemudian dianalisa untuk memahami tingkat pemahaman dan miskonsepsi mahasiswa. Adapun sebaran tingkat pemahaman mahasiswa tiap Kompetensi Dasar ditunjukkan pada Tabel 3.

Tabel 3 Prosentase Tingkat Pemahaman Konsep Mahasiswa Tadris Fisika UIN Mataram

\begin{tabular}{|c|c|c|c|c|c|}
\hline \multirow{2}{*}{ NO } & \multirow{2}{*}{ KOMPETENSI DASAR } & \multicolumn{4}{|c|}{ TINGKAT PEMAHAMAN (\%) } \\
\hline & & PP & PS & MK & $\mathrm{TP}$ \\
\hline \multirow[t]{3}{*}{1} & Memahami $\quad$ konsep $\quad$ Hukum & 61,67 & 26,67 & 10,00 & 1,67 \\
\hline & Coulomb dalam Sistem Muatan & & & & \\
\hline & Titik dan Terdistribusi Kontinu & & & & \\
\hline \multirow[t]{4}{*}{2} & Menganalisis tentang medan & 43,75 & 11,25 & 37,50 & 7,50 \\
\hline & listrik pada beberapa distribusi & & & & \\
\hline & muatan serta menentukan & & & & \\
\hline & konservasi medan listrik & & & & \\
\hline
\end{tabular}




\begin{tabular}{cccccc}
\hline 3 & $\begin{array}{l}\text { Menganalisa potensial skalar } \\
\text { pada beberapa distribusi muatan }\end{array}$ & 23,33 & 46,27 & 27,33 & 6,67 \\
\hline Rata-Rata & 42,92 & 28,19 & 23,61 & 5,28 \\
\hline
\end{tabular}

Keterangan:

PP : Pemahaman Penuh

PS : Pemahaman Sebagian

MK : Miskonsepsi

TP : Tidak Paham

Berdasarkan Tabel 3 tampak bahwa rata-rata tingkat pemahaman penuh mahasiswa Tadris Fisika UIN Mataram mencapai 42,92\% dan 23,61 \% mahasiswa mengalami miskonsepsi. Hal ini mengindikasikan bahwa tingkat pemahaman mahasiswa Tadris Fisika cukup bagus.

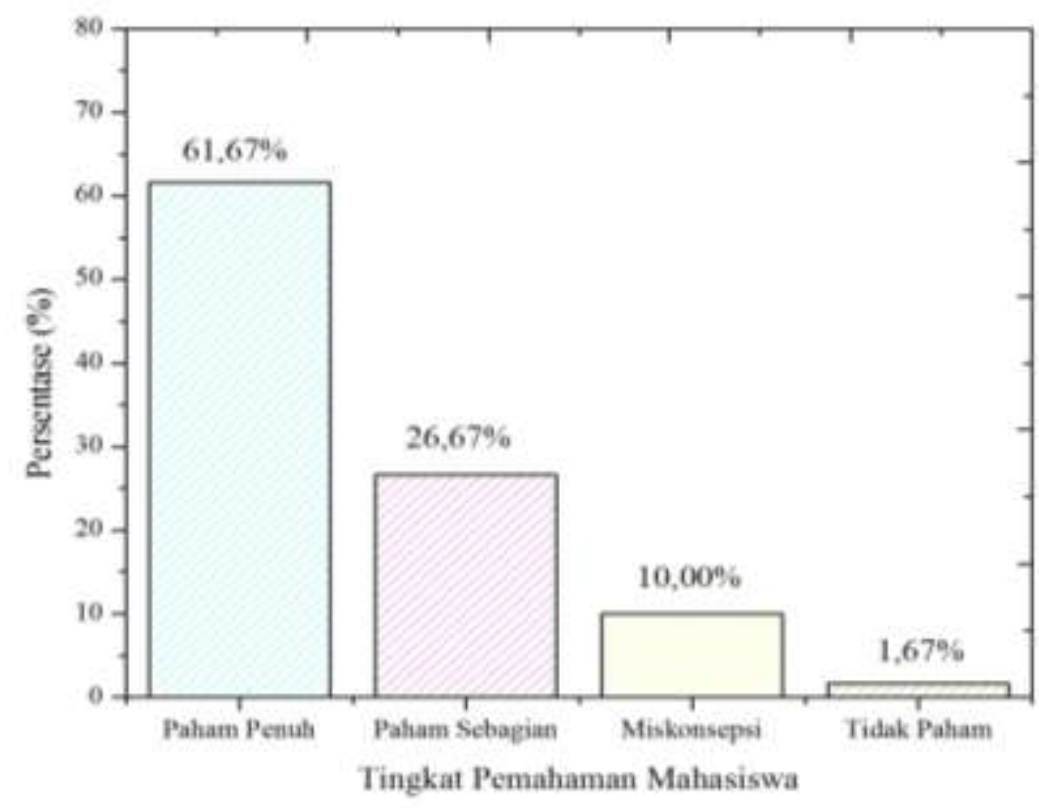

Gambar 2 Tingkat Pemahaman Konsep Mahasiswa Tadris Fisika pada Sub Materi Gaya Coulomb

Gambar 2 menggambarkan tingkat pemahaman mahasiswa tadris fisika pada sub materi gaya coulomb. Pada sub materi gaya coulomb, tingkat pemahaman penuh mahasiswa fisika mencapai $61,67 \%$. Sedangkan prosentase miskonsepsi mahasiswa tergolong kecil yaitu mencapai 10,00 \%. Hal ini mengindikasikan bahwa mahasiswa tadris fisika UIN Mataram dapat menangkap mata kuliah dengan baik pada materi Gaya 
Coulomb. Materi gaya coulomb tergolong materi dasar sehingga mahasiswa dapat menangkap mata kuliah dengan baik.

Gambar 3 menggambarkan tingkat pemahaman mahasiswa tadris fisika pada sub materi medan listrik. Pada sub materi medan listrik, tingkat pemahaman penuh mahasiswa fisika mencapai $43,75 \%$. Prosentase miskonsepsi mahasiswa tergolong cukup besar yaitu mencapai 37,50\%. Jika dibandingkan dengan tingkat pemahaman penuh pada materi gaya coulomb, tingkat pemahaman penuh mahasiswa pada materi medan listrik tergolong rendah bahkan prosesntase miskonsepsinya tergolong tingi.

Hal ini sangat mungkin terjadi pada saat mahasiswa menganalisa medan listrik pada bola bermuatan yang terdistribusi kontinu. Pemahaman mahasiswa mengenai koordinat bola masih tergolong rendah karena mahasiswa terbiasa menganalisa sistem fisis pada koordinat kartesius.

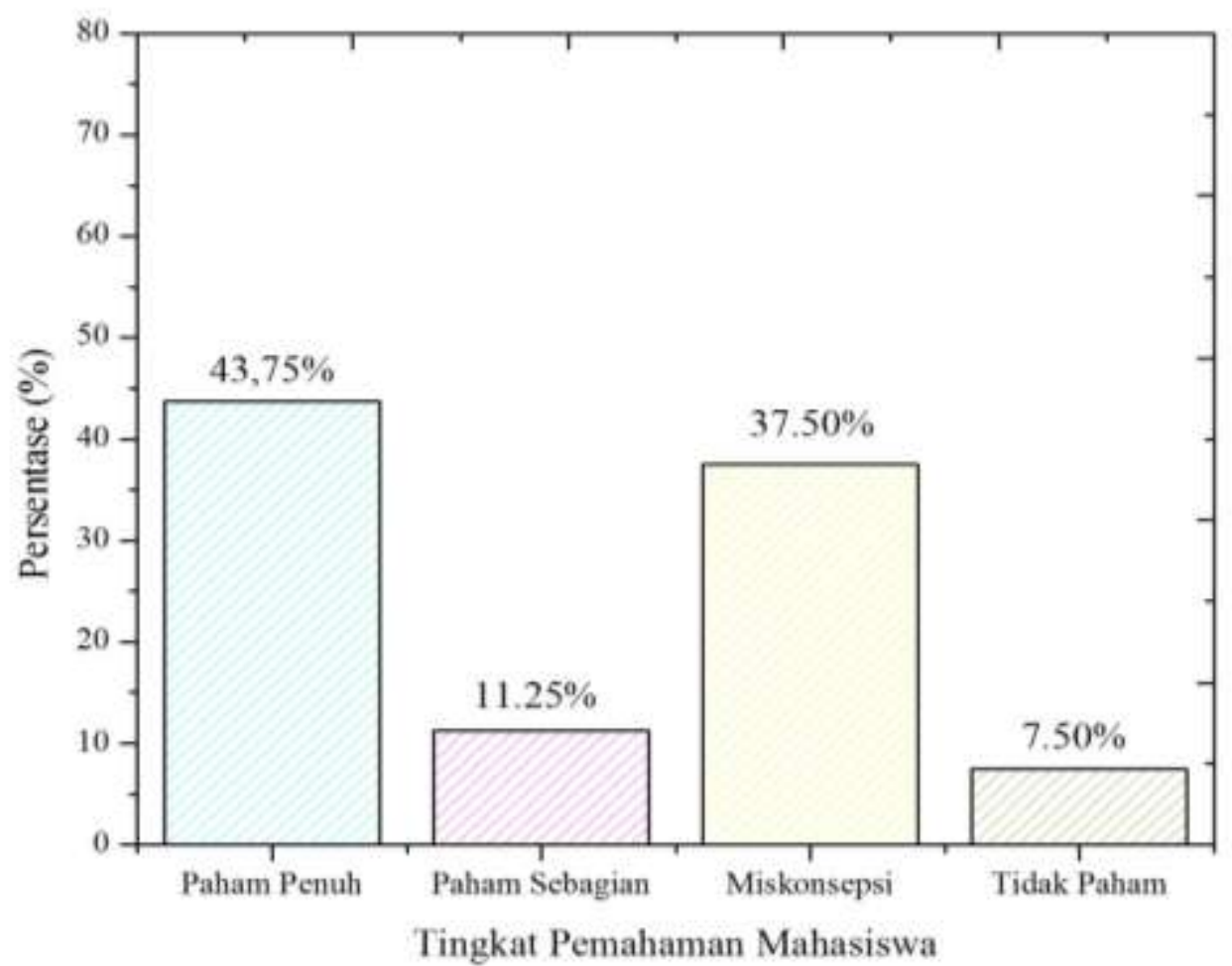

Gambar 3 Tingkat Pemahaman Konsep Mahasiswa Tadris Fisika pada Sub Materi Medan Listrik

Gambar 4 menggambarkan tingkat pemahaman mahasiswa tadris fisika pada sub materi potensial listrik. Pada sub materi potensial listrik, tingkat pemahaman penuh mahasiswa fisika cukup rendah mencapai $23,33 \%$. Persentase miskonsepsi mahasiswa 
mencapai $27,33 \%$. Namun, jumlah mahasiswa yang hanya faham sebagian cukup tinggi yaitu mencapai $46,27 \%$. Hal ini cukup ironis karena secara analisis materi mengenai potensial listrik merupakan materi yang tergolong mudah. Besaran potensial yang bersifat skalar memungkinkan mahasiswa untuk menganalisis secara langsung tanpa harus memperhatikan arah terlebih dahulu sehingga tidak rumit seperti menganalisis medan listrik. Penyebab rendahnya tingkat pemahaman mahasiswa kemungkinan disebabkan karena peggunaan operator diferensial seperti grad dalam analisa potensial listrik, terlebih apabila mahasiswa menentukan potensial listrik pada koordinat bola. Penyebab rendahnya pemahaman mahasiswa yang lain juga karena mahasiswa masih sulit membedakan besaran listrik statis mana yang scalar dengan vektor. Besaran potensial listrik merupakan besaran skalar namun masih banyak mahasiswa yang menganalisis menggunakan besaran scalar. Hal ini yang bayak mengakibatkan mahasiswa kurang yakin dengan jawabannya sehingga prosentase mahasiswa yang paham sebagian tergolong tinggi.

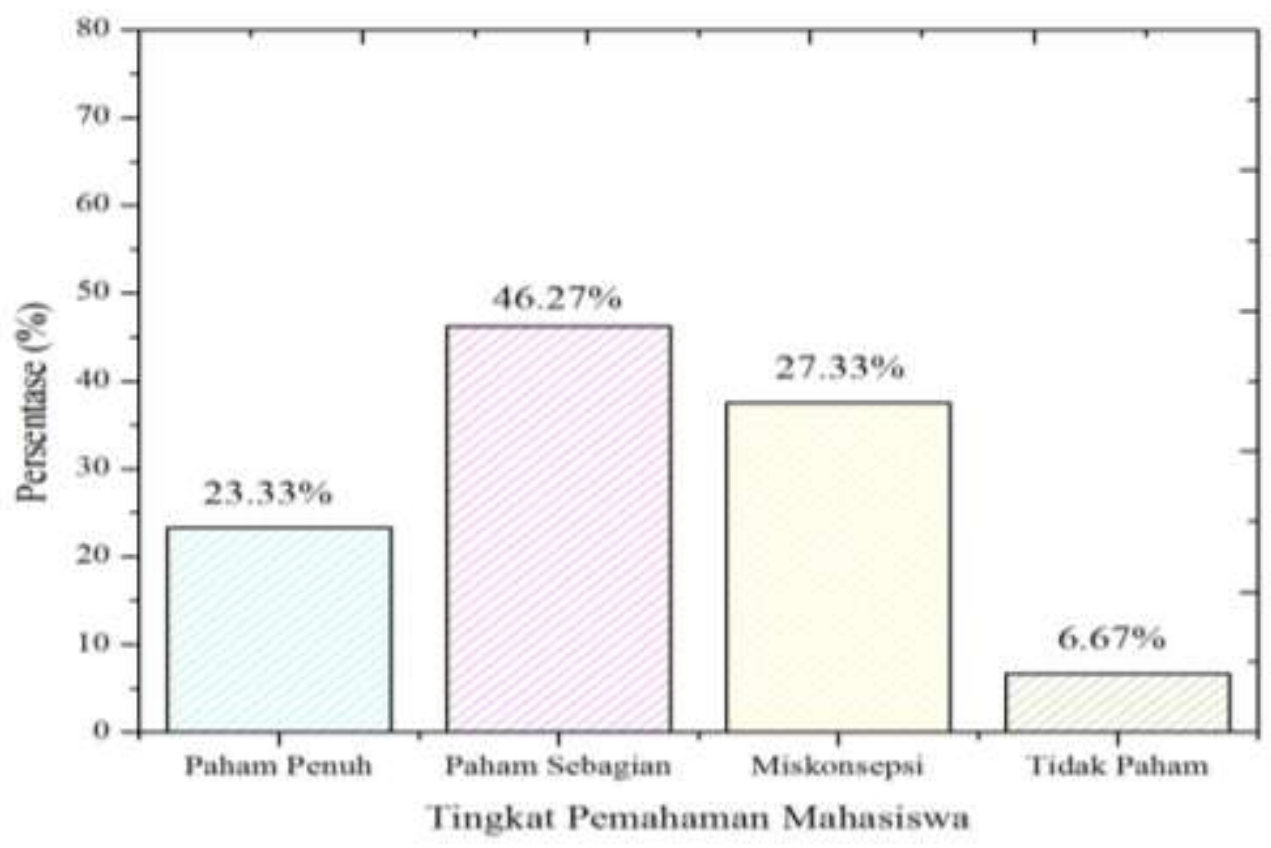

Gambar 4 Tingkat Pemahaman Konsep Mahasiswa Tadris Fisika pada Sub Materi Potensial Listrik

Gambar 5 Menunjukkan grafik miskonsepsi mahasiswa pada materi listrik statis. Secara umum, miskonsepsi mahasiswa sebanyak 23,61\%. Sub materi medan listrik merupakan submateri dengan persentase terbesar yaitu sebesar $37,50 \%$ dan gaya 
coulomb merupakan submateri dengan persentase miskonsepsi terendah yaitu sebesar 10\%. Jumlah ini masih tergolong wajar karena menurut Ditjen Manajemen Pendidikan Dasar dan Menengah (2007) adalah batas kesalahan yang terjadi sebesar 75\%. Walau demikian, pada tiap kompetensi dasar, masih saja mahasiswa yang mengalami miskonsepsi.

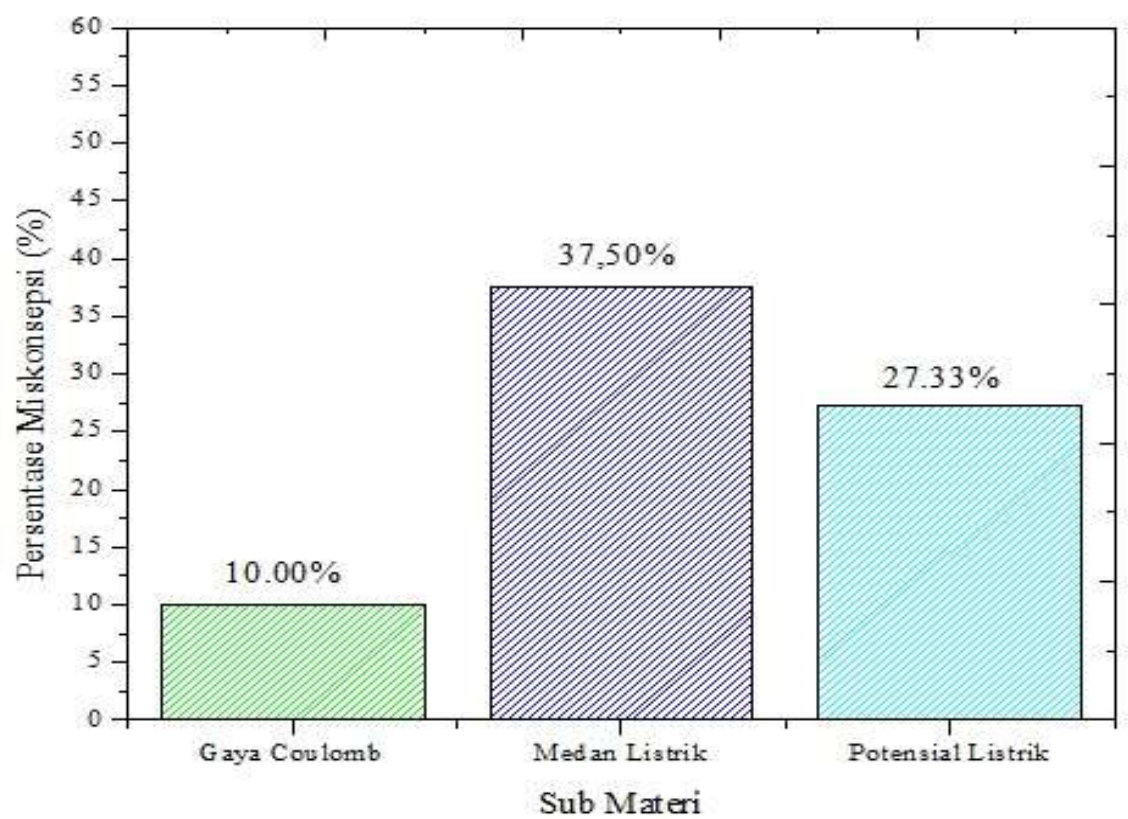

Gambar 5 Grafik Persentase Miskonsepsi Mahasiswa pada Materi Listrik Statis

Dalam penelitian ini, mahasiswa diakatakan mengalami miskonsepsi apabila memiliki jawaban dan alasan yang salah namun memiliki tingkat keyakinan tinggi terhadap jawabannya. Secara garis besar, penyebab miskonsepsi yang dialami oleh mahasiswa dapat dikelompokkan ke dalam 5 hal yaitu: mahasiswa, dosen, buku teks, konteks, dan metode mengajar (Analisa Fitria. 2014). Ada beberapa penyebab yang datang dari siswa antara lain, kemampuan, minat dan cara berfikir mahasiswa serta pengaruh dari teman pergaulan. Penyebab kesalahan dosen antara lain kurangnya penguasaan konsep, kurangnya persiapan mengajar, cara mengajar dosen yang kurang tepat dan kurangnya sikap dosen sehingga mengakibatkan kurangnya hubungan dengan mahasiswa. Konteks yang dimaksud adalah adanya anggapan umum yang sebenarnya merupakan suatu miskonsepsi sehingga diikuti kembali oleh mahasiswa.

Metode mengajar yang hanya menekankan satu segi pemikiran juga dapat mengakibatkan miskonsepsi pada mahasiswa. Terutama untuk materi listrik statis. Ada banyak langkah atau cara yang dapat digunakan oleh mahasiswa untuk menyelesaikan 
kasus listrik statis.

Gaya Coulomb adalah penyumbang miskonsepsi terkecil. Hal ini wajar karena dalam kasus gaya coulomb mahasiswa sudah terbiasa menentukan arah vektor dengan satu konsep, apabila muatan sejenis didekatkan maka kedua muatan akan tolak menolak sedangkan apabila muatan berlawanan jenis didekatkan maka kedua muatan akan saling tarik menarik. Beda halnya dengan medan listrik yang merupakan penyumbang miskonsepsi terbesar. Ada dua cara menentukan arah medan listrik mengakibatkan mahasiswa mengalami kesalahan dalam menentukan besarnya medan listrik. Sehingga walaupun cara mahasiswa salah, namun mereka tetap yakin akan jawabannya.

\section{SIMPULAN}

Rata-rata tingkat pemahaman penuh mahasiswa Tadris Fisika UIN Mataram mencapai $42,92 \%$ dan $23,61 \%$ mahasiswa mengalami miskonsepsi. Pada sub materi gaya coulomb, tingkat pemahaman penuh mahasiswa fisika mencapai 61,67 \%. Sedangkan prosentase miskonsepsi mahasiswa tergolong kecil yaitu mencapai $10,00 \%$. Pada sub materi medan listrik, tingkat pemahaman penuh mahasiswa fisika mencapai 43,75\% sedangkan persentase miskonsepsi mahasiswa tergolong cukup besar yaitu mencapai 37,50 \%. Pada sub materi potensial listrik, tingkat pemahaman penuh mahasiswa fisika cukup rendah mencapai $23,33 \%$. Prosentase miskonsepsi mahasiswa mencapai $27,33 \%$. Namun, jumlah mahasiswa yang hanya faham sebagian cukup tinggi yaitu mencapai $46,27 \%$. 


\section{DAFTAR PUSTAKA}

Ambarwati, Roro Dwi. 2011. Miskonsepsi pada Materi Kelistrikan, Kemagnetan, dan Tata Surya Siswa SMP. Skripsi Jurusan Fisika FMIPA Universitas Negeri Semarang

Arikunto, Suharsimi. 2006. Prosedur Penelitian Suatu Pendekatan Praktik (edisi revisi). Jakarta: Bumi Aksara

Berg, Euwe Van Den. 1991. Miskonsepsi Fisika dan Remidiasi. Pengantar Lokakarya di Universitas Kristen Satya Wacana 7 - 10 Oktober 1990. Salatiga: Universitas Kristen Satya Wacana

Desvi. 2009. Analisis Miskonsepsi siswa SMA PGRI Padang Kelas XI IPA Dalam Materi Kesetimbangan dengan Remidiasi. www.scribd.com. Diakses 24 Desember 2018

Fitria, Analisa. 2014. Miskonsepsi Mahasiswa dalam Menentukan Grup pada Struktur Aljabar Menggunakan Certainty of Response Index (CRI) di Jurusan Pendidikan Matematika IAIN Antasari. JPM IAIN Antasari Vol. 01 No. 2 Hal. 45-60

Frederick J. Bueche. 1999. Seri Buku Schaum Teori dan Soal-Soal Fisika Edisi Delapan (terjemahan). Jakarta: Penerbit Erlangga

Griffiths, D. J. 1994. Introduction to Electromagnetics. Prectice Hall: New Jersey

Gurel, D. K., A. Eryilmaz, dan L. C. McDermott. (2015). A Review and Comparison of Diagnostic Instruments to Identify Students' Misconception in Science. Eurasia Journal of Mathematics, Science, \& Technology Education, 11 (5): 989-1008.

Khasanah, Uswatun dan Setiawan, Agus. 2015. Survey Konsepsi Mahasiswa Calon Guru Fisika pada Konsep Listrik Statis Menggunakan TKLS dengan Format Tes Pilihan Ganda Respon erbuk."Dalam Prosiding Simposium Nasional Inovasi dan Pembelajaran Sains 2015 (SNIPS 2015) 8 dan 9 Juni 2015, Bandung,Indonesia".(Online). http://portal.fi.itb.ac.id/snips2015/files/snips_2015_uswatun_khasanah_c73602 9a701fd16c871be77d03a2ec10.pdf),

Kucuk, M., S. Cepni, dan M. Gokdere. 2005. Turkish Primary Schools Students' Alternative Conception about Work, Power and Energy. Journal of Physics Teacher Education Online, 3(2): 22-28. Online. Tersedia di http://jpteo.com [diakses 30-09-2018].

Aufa Maulida Fitrianingrum, Sarwi, Budi Astuti. 2017. Penerapan Instrumen Three-Tier Test untuk Mengidentifikasi Miskonsepsi Siswa SMA pada Materi 
Keseimbangan Benda Tegar. Jurnal Phenomenon. 7 (2). 88-98

Pesman, Haki. 2005. Development of Three Tier Test to Assess Ninth Grade Students Misconception About Simple Electric Circuits. Thesis

Sri Wahyuningsih, Ani Rusilowati, Nathan Hindarto. 2018. Analisis Miskonsepsi Literasi Sains Menggunakan Three Tier Multiple Choice Test Materi Cahaya.

Jurnal Phenomenon. 8 (2). 114-128.

Sukadi, Eti dan Sari, Ira Novita. 2013. Miskonsepsi Mahasiswa Pendidikan Fisika STKIP PGRI Pontianak pada materi Listrik Statis. "Dalam Jurnal Pendidikan Informatika Sains, Vol, 2, No,2, Desember 2013". (Online).

http://journal.ikippgriptk.ac.id/index.php/saintek/article/viewFile/220/219.

Suparno, P. 2010. Metode Penelitian Pendidikan Fisika. Yogyakarta: Universitas Sanata Dharma.

Suparno, P. (2005). Miskonsepsi dan Perubahan Konsep dalam Pendidikan Fisika. Jakarta: PT. Grasindo Anggota Ikapi.

Suparno, Paul. 2007. Metodologi Pembelajaran Fisika Konstruktivistik \& Menyenangkan. Yogyakarta: Universitas Sanata Dharma.

Tayubi, Y. R. 2005. Identifikasi Miskonsepsi pada Konsep-Konsep Fisika Menggunakan Certainty of Response Index (CRI). Mimbar Pendidikan No 3/X/XIV/2005. Bandung: Universitas Pendidikan Indonesia. 